Supporting Information for:

\title{
Controlling the Biological Effects of Spermine using a Synthetic Receptor
}

\author{
Laurent Vial, R. Frederick Ludlow, Julien Leclaire, Ruth Pérez-Fernández, Sijbren \\ Otto \\ Department of Chemistry, University of Cambridge, Lensfield Road, Cambridge CB2 \\ 1EW, United Kingdom. E-mail: so230@cam.ac.uk
}

\section{Contents}

COSY spectrum of the complex between spermine and $6 . \quad$ S2

$\begin{array}{ll}\text { LC-MS analysis of } 6 . & \text { S2 }\end{array}$

ITC studies of binding of spermine to $6 . \quad$ S3

$\begin{array}{ll}\text { Computer simulation results. } & \text { S4 }\end{array}$ 


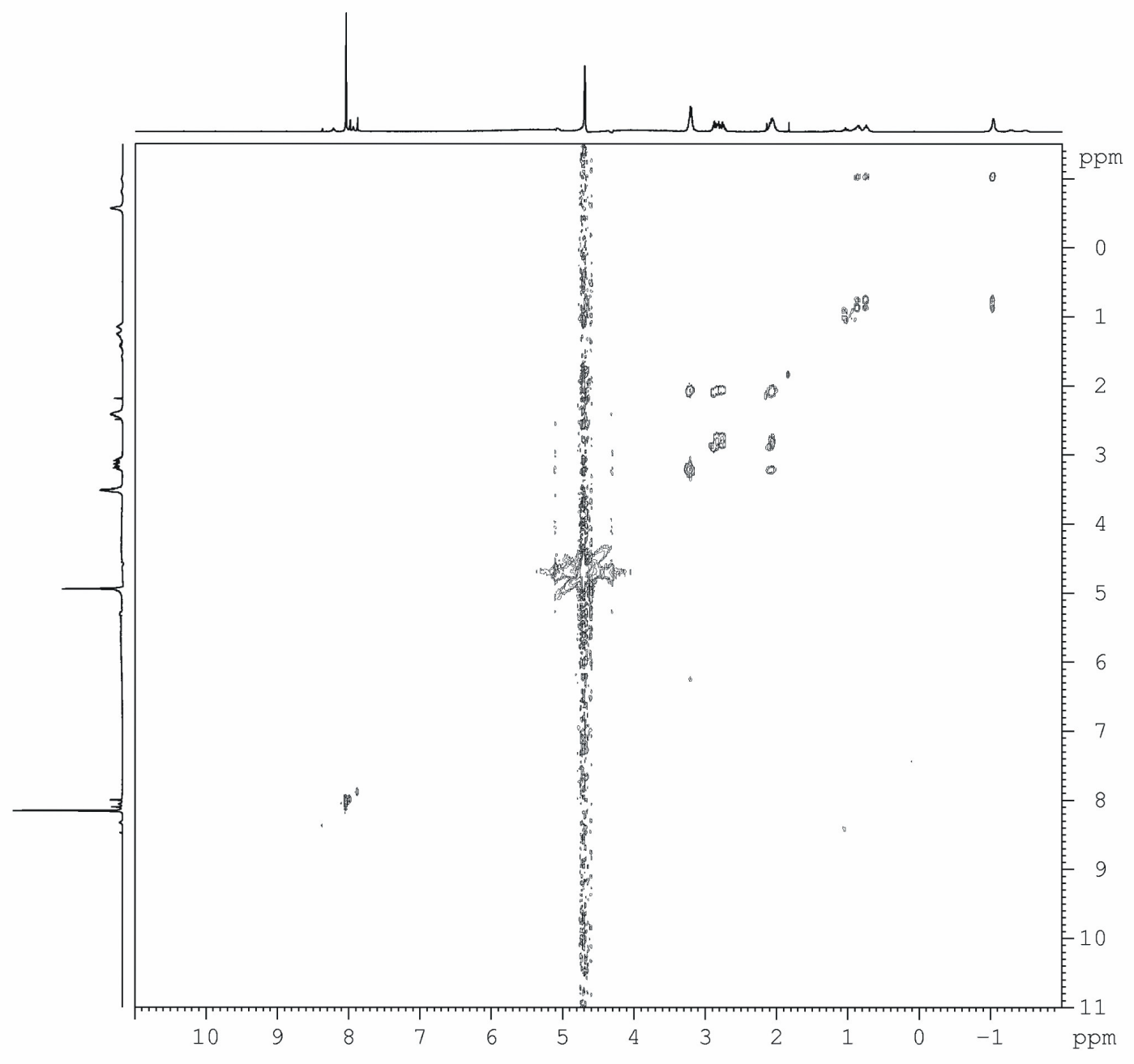

Figure S1. COSY spectrum of the complex between spermine and 6. Solvent: $89 \mathrm{mM}$ phosphate buffer (pH 7.4, 11\% D2O)

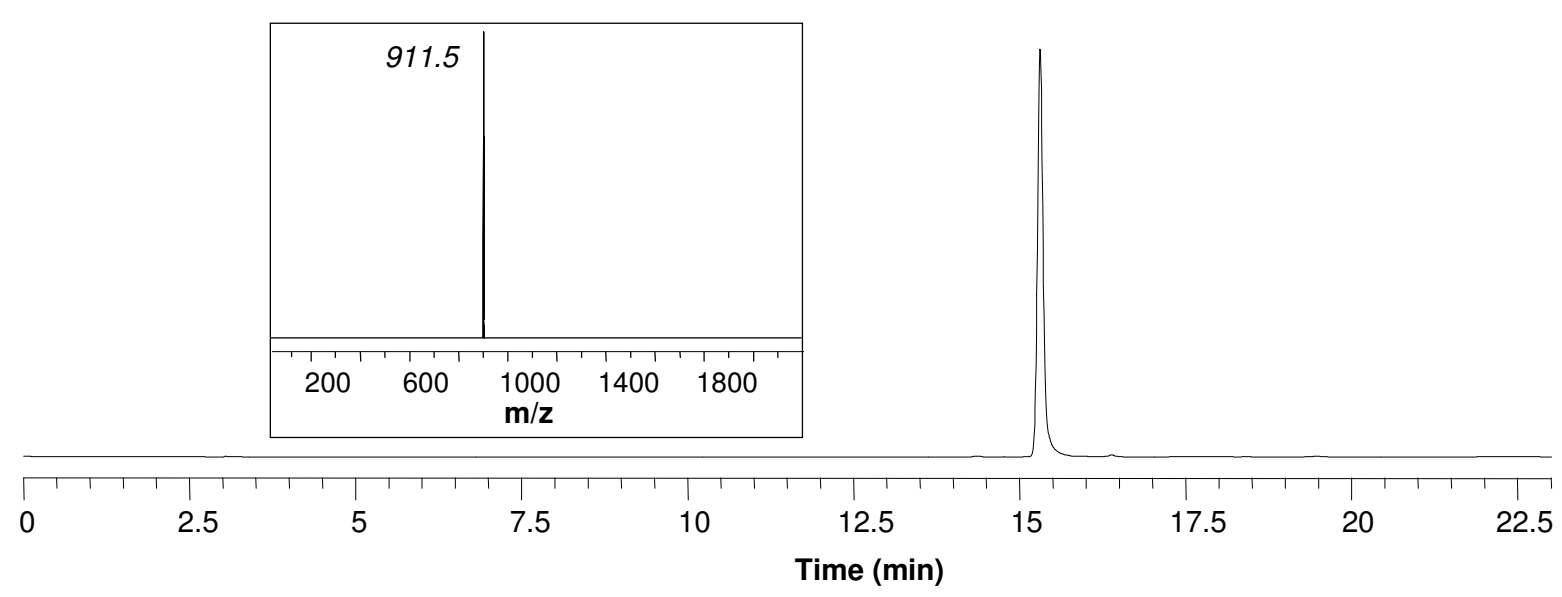

Figure S2. HPLC and MS (inset) analysis of 6. 


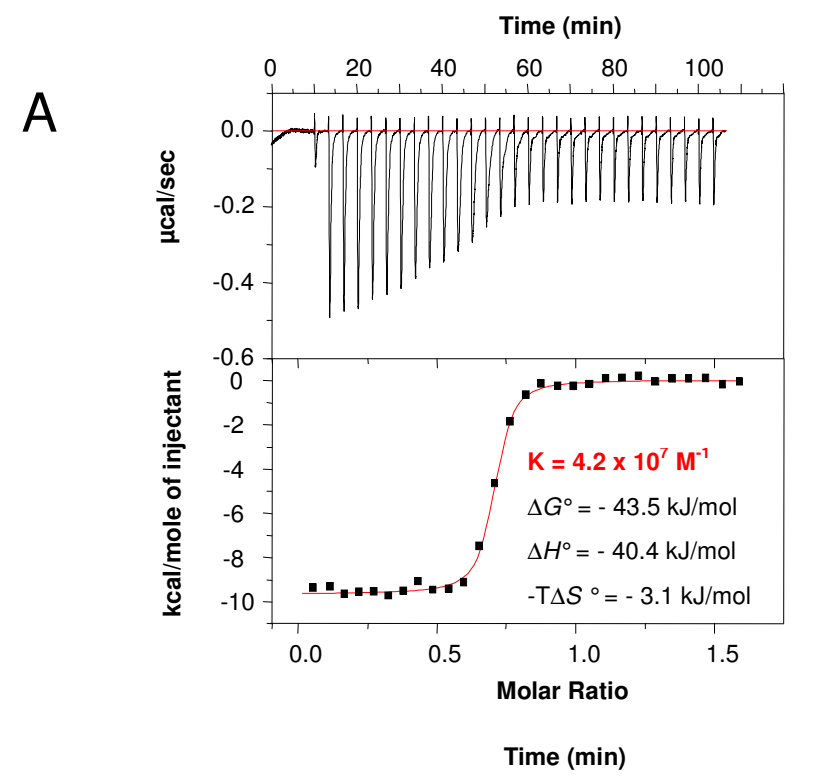

B
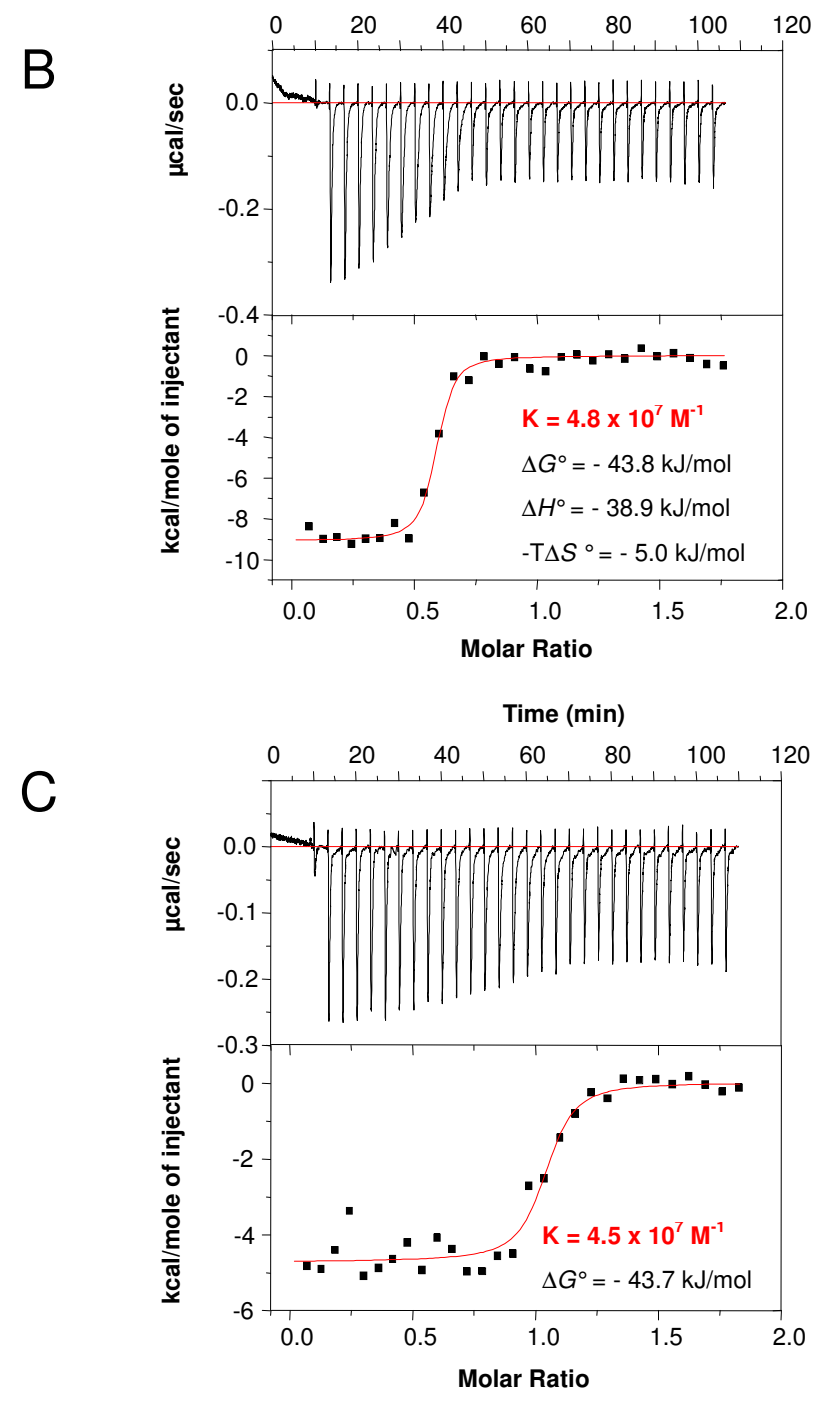

Figure S3. ITC data. Concentrations of $\mathbf{1}$ and $\mathbf{6}$ are $0.1068 \mathrm{mM}$ and $0.0156 \mathrm{mM}(\mathrm{A}), 0.0739 \mathrm{mM}$ and $0.0098 \mathrm{mM}(\mathrm{B}), 0.0528 \mathrm{mM}$ and $0.0070 \mathrm{mM}(\mathrm{C})$ respectively. 
Table S1. Energies of the free receptors and complexes as determined by molecular dynamics simulations.

\begin{tabular}{llll}
\hline \multirow{2}{*}{$\begin{array}{l}\text { Relative } \\
\text { configurations } \\
\text { of the disulfide bonds }\end{array}$} & $\begin{array}{l}\text { MD Energies } \\
\text { Average Total Energy } \\
\left(\mathrm{kJmol}^{-1}\right)\end{array}$ & $\begin{array}{l}\text { Relative }_{\text {MD Energies }}^{(a)} \\
\left(\mathrm{kJmol}^{-1}\right)\end{array}$ \\
\hline Receptor & $(P, P, P, P)$ & -1785.89 & 5.83 \\
& $(P, P, P, M)$ & -1786.73 & 4.99 \\
& $(P, P, M, M)$ & -1784.50 & 7.22 \\
& $(P, M, P, M)$ & -1791.72 & 0 \\
\hline \multirow{3}{*}{ Complex } & $(P, P, P, P)$ & -2735.61 & 0 \\
& $(P, P, P, M)$ & -2718.94 & 16.67 \\
& $(P, P, M, M)$ & -2715.36 & 20.25 \\
& $(P, M, P, M)$ & -2693.90 & 41.71 \\
\hline
\end{tabular}

(a) MD energy relative to the most stable stereoisomer. 